\title{
INVESTIGATIONS OF THE NATURE OF $t$-ALLELES IN THE MOUSE
}

\section{SHORT TESTS OF SOME FURTHER MUTANT ALLELES}

\author{
MARY F. LYON and R. MEREDITH \\ M.R.C. Radiobiological Research Unit, Harwell, Didcot, Berkshire
}

Received 16.i.64

IN the previous two papers of this group (Lyon and Meredith, I964a and $b$ ) extensive genetical analysis of a number of mutant $t$-alleles led to the formulation of a hypothesis concerning the chromosomal abnormality present in them. After the hypothesis had been formulated further mutations continued to occur, but these were put to less extensive test and only enough was done to test the main points thought to have emerged from the studies of the earlier mutants. Some confirmatory points were indeed found and the results are briefly reported here, together with the data incidentally obtained on the frequency of mutant animals in the $t^{6}$ and $t^{h 7}$ stocks.

\section{RESULTS}

Table I gives a list of the new alleles, arranged in groups according to the allele from which they arose. Seven alleles definitely arose from $t^{6}$, and of these five were detected as crossovers between $T$ and a nearby marker (including one in the $T_{1} g$ o translocation stock) and two were detected as normal-tailed mutants in a balanced lethal tailless stock. All five crossovers were shown to carry mutant $t$-alleles which lacked the $t^{6}$ lethal factor and were viable when homozygous. The two normal-tailed exceptions likewise carried viable mutant alleles which, since the mutant chromosome carried $t f$, must have arisen through crossing-over.

The allele $t^{h 16}$ (derived from $t^{h 7}$ ) was indistinguishable from $t^{6}$ and therefore would be expected to give rise to the same types of mutants. The one allele which definitely and the two which possibly arose from it were indeed similar to those derived from $t^{6}$; they had arisen by crossing-over between $T$ and $t f$ and had lost the $t^{\theta}$-lethal factor.

From $t^{h 7}$ various kinds of mutant were found in the earlier studies; there were two complementary types of crossover between $T$ and $t f$ and two types of presumed crossovers between the two halves of the postulated duplication of the $T$-modifying factor. Only one of these was represented among the alleles reported here and this was one of the tailless types resulting from crossing-over between the halves of the duplication. Both these alleles, $t^{h 24}$ and $t^{h 27}$, carried the wildtype 
allele of tufted and so were expected to be indistinguishable from $t^{6}$. They did indeed prove to be lethal both when homozygous and when in compound with $t^{6}$, but their other properties were not tested.

The one remaining allele, $t^{h 25}$, unfortunately told nothing, as it was not possible to determine whether it had arisen from $t^{6}$ or from $t^{h 15}$.

The data on the frequency of exceptional animals in the $t^{6}$ and $t^{t h}$ stocks are presented in table 2. The genotype of the $t^{6}$ balanced lethal

TABLE I

Origin and genetic tests of thirteen mutant $t$-alleles

\begin{tabular}{|c|c|c|c|c|c|}
\hline \multirow{2}{*}{ Stock of origin } & \multirow{2}{*}{$\underset{t^{t n}}{\text { Allele }}$} & \multicolumn{2}{|c|}{ Original animal } & \multicolumn{2}{|c|}{ Viability } \\
\hline & & Phenotype & Genotype & $t^{8} t^{h n}$ & $t^{h n} t^{h n}$ \\
\hline$T t f / t^{8}+$ & $\begin{array}{l}t^{h 12} \\
t^{h 21} \\
t^{h 28} \\
t^{h 29} \\
t^{h 30} \\
t^{h 31}\end{array}$ & $\begin{array}{l}\text { tailless tufted } \\
\text { normal tailed } \\
\text { normal tailed } \\
\text { tailless tufted } \\
\text { tailless tufted } \\
\text { tailless tufted }\end{array}$ & $\begin{array}{l}\text { Ttf/t } t^{h 12} t f \\
t^{\theta}+/ t^{h 21} t f \\
t^{6}+/ t^{h 28} t f \\
T t f / t^{h 2 \theta} t f \\
T t f / t^{h 80} t f \\
T t f / t^{h 81} t f\end{array}$ & $\begin{array}{l}\text { viable } \\
\text { viable } \\
\text { viable } \\
\text { viable } \\
\text { viable } \\
\text { viable }\end{array}$ & $\begin{array}{l}\text { viable } \\
\text { viable } \\
\text { viable } \\
\text { viable } \\
\text { viable } \\
\text { viable }\end{array}$ \\
\hline$T+\mid t^{6} \operatorname{Tr} 90$ & $t^{h 19}$ & tailless fully fertile & $T+\mid t^{t 19}+$ & viable & viable \\
\hline $\begin{array}{l}T_{t f} / t^{8}+\times T_{t f} / t^{h 18}+ \\
T t f / t^{h 16}+.\end{array}$ & $\begin{array}{l}t^{h 22} \\
t^{h 28} \\
t^{226}\end{array}$ & $\begin{array}{l}\text { normal tailed } \\
\text { normal tailed } \\
\text { normal tailed }\end{array}$ & $\begin{array}{l}t^{6}+/ t^{h 22} t f \\
t^{8}+/ t^{h 28} t f \\
+t f / t^{h 2} t f\end{array}$ & $\begin{array}{l}\text { viable } \\
\text { viable } \\
\text { viable }\end{array}$ & $\begin{array}{l}\text { viable } \\
\text { viable } \\
\text { viable }\end{array}$ \\
\hline$T_{t f / t^{h 7}}+$ & $\begin{array}{l}t^{h 24} \\
t^{h 27}\end{array}$ & $\begin{array}{l}\text { tailless non-tufted } \\
\text { tailless non-tufted }\end{array}$ & $\begin{array}{l}T t f / t^{h 24}+ \\
T t f / t^{227}+\end{array}$ & $\begin{array}{l}\text { lethal } \\
\text { lethal }\end{array}$ & $\begin{array}{l}\text { lethal } \\
\text { lethal }\end{array}$ \\
\hline$T t f / t^{h 15} t f \times t^{6}+\mid t^{h 15} t f$ & $t^{h 25}$ & tailless tufted & $T t f / t^{h 25} t f$ & viable & viable \\
\hline
\end{tabular}

line was $T t f\left|t^{6}+\times T t f\right| t^{6}+$ and all offspring were expected to be tailless non-tufted, with exceptional animals either normal-tailed or tufted. Previous data concerning this stock were derived from the control series of a radiation experiment (Lyon, I960). The new data were in reasonably good agreement with the old, and the total frequency of normal-tailed exceptions agreed with that reported by Dunn, Bennett and Beasley (1962) for $t^{0}$, an allele identical with $t^{6}$. By contrast, the frequency of tufted exceptions was more than three times that of the normal-tailed ones, whereas, owing to the abnormally high male segregation ratio of $t^{6}$, it would have been expected to be somewhat lower. However, the difference was not statistically significant.

The $t^{h 7}$ balanced lethal stock was genetically $T t f / t^{h 7}+\times T t f / t^{h 7}+$ and all offspring were expected to be normal-tailed non-tufted, with 
exceptions being tailless or tufted. The tailless animals would arise through crossing-over between the two halves of the postulated duplication of the $T$-modifying factor and the tufted animals through crossingover anywhere in the abnormal region. Three tailless and no tufted young were found and the frequency of tailless exceptions was about four times that of normal-tailed exceptions in the $t^{6}$ stock, suggesting that crossing-over within the duplication occurred more frequently

TABLE 2

The frequency of mutant animals in the $t^{6}$ and $t^{\text {hi }}$ stocks

\begin{tabular}{|c|c|c|c|c|c|}
\hline Stock & & $\begin{array}{c}\text { Normal } \\
\text { tailed }\end{array}$ & Total & Tufted & Total \\
\hline \multirow[t]{3}{*}{$t^{6}$} & $\begin{array}{l}\text { Old data } \\
\text { New data }\end{array}$ & $\begin{array}{l}1 \\
2\end{array}$ & $\begin{array}{l}1539 \\
1577\end{array}$ & $\begin{array}{l}2 \\
4\end{array}$ & $\begin{array}{r}898 \\
1079\end{array}$ \\
\hline & Total & 3 & $3^{116}$ & 6 & I 977 \\
\hline & $\begin{array}{l}\text { Frequency of exceptions } \\
\text { Fiducial limits ( } 5 \text { per cent.) }\end{array}$ & \multicolumn{2}{|c|}{$\begin{array}{c}0.00096 \\
0 \cdot 000199-0 \cdot 0028 \mathrm{I}\end{array}$} & \multicolumn{2}{|c|}{$\begin{array}{c}0.00303 \\
0.00111-0.00661\end{array}$} \\
\hline \multirow{3}{*}{$t^{h 7}$} & & Tailless & Total & Tufted & Total \\
\hline & & 3 & 695 & 0 & 509 \\
\hline & $\begin{array}{l}\text { Frequency of exceptions } \\
\text { Fiducial limits ( } 5 \text { per cent.) }\end{array}$ & \multicolumn{2}{|c|}{$\begin{array}{c}0.00432 \\
0.000891-0 \cdot 01262\end{array}$} & \multicolumn{2}{|c|}{-0.00725} \\
\hline
\end{tabular}

than crossing-over at other points in the region. However, the fiducial limits of the observed frequency were so wide that this point cannot be considered to be established.

\section{DISCUSSION}

In general the alleles described in this paper show that the types of mutants described in the previous two papers were due to repeatable events. In particular, the alleles $t^{h 24}$ and $t^{h 27}$, postulated to be derived from $t^{h 7}$ by crossing-over between the two halves of a duplication, bring the total number of observed crossovers of this type to four, and show that this particular change occurs repeatedly. Of the main types of mutation or crossover found, the only one that has not been found more than once is the mutation from $t^{6}$ to $t^{h}$. It is of interest that the original $t^{h}$-carrying mutant was the offspring of an irradiated father, whose spermatogonia had received 6oor of X-rays (Lyon, i 960 ). Hence it is possible that the event leading to the origin of $t^{h 7}$ was radiation-induced and occurs rarely or never under normal conditions. 


\section{REFERENCES}

DUNN, L. C., BENNETT, D., AND BEASLEY, A. B. I962. Mutation and recombination in the vicinity of a complex gene. Genetics, 47, 285-303.

LYON, M. F. 1960. Effect of X-rays on the mutation of $t$-alleles in the mouse. Heredity, 14 , 247-252.

LYON, M. F., AND MEREDITH, R. 1964a. Investigations of the nature of $t$-alleles in the mouse. I. Genetic analysis of a series of mutants derived from a lethal allele. Heredity, 19, 30 I-3 2.

LYON, M. F., AND MEREDITH, R. I964b. Investigations of the nature of $t$-alleles in the mouse. II. Genetic analysis of an unusual mutant allele and its derivatives. Heredity, 19, 313-325. 